\title{
Guide of attributes of the nurse's political competence: a methodological study
}

\author{
Guia de atributos da competência política do enfermeiro: estudo metodológico
}

Guía de atribuciones de la competencia política del enfermero: estudio metodológico

\author{
Wesley Soares de Melo', Paulo Jorge Ferreira de Oliveira", Flávia Paula Magalhães Monteiro"I', \\ Francisca Carla dos Angelos Santos ${ }^{\mathrm{IV}}$, Maria Janaína Nogueira da Silvav , Carolina Jimenez Calderon ${ }^{\mathrm{VI}}$, \\ Lilian Nara Amaral da Fonseca ${ }^{\mathrm{VII}}$, Ana Adélia Chaves Simão ${ }^{\mathrm{VIII}}$ \\ ' Boa Viagem Town Hall, Health Secretariat, Department of Basic Health Care. Boa Viagem, Ceará, Brazil. \\ "Centro Universitário Católica de Quixadá, Nursing Department. Quixadá, Ceará, Brazil. \\ "II Universidade da Integração Internacional da Lusofonia Afro-Brasileira, \\ Institute of Health Sciences, Nursing Department. Acarape, Ceará, Brazil. \\ Iv Baturité Town Hall, Health Secretariat, Department of Basic Health Care. Baturité, Ceará, Brazil. \\ $\checkmark$ Ibaretama Town Hall, Health Secretariat, Department of Basic Health Care. Ibaretama, Ceará, Brazil. \\ ${ }^{V I}$ Quixadá Town Hall, Health Secretariat, Emergency Room Unit. Quixadá, Ceará, Brazil. \\ VII Government of the State of Ceará, Health Secretariat, Dr. Carlos Alberto Studart Gomes Hospital. Fortaleza, Ceará, Brazil. \\ VIII Pedra Branca Town Hall, Health Secretariat, São Sebastião Municipal Hospital. Pedra Branca, Ceará, Brazil.
}

How to cite this article:

Melo WS, Oliveira PJF, Monteiro FPM, Santos FCA, Silva MJN, Calderon CJ, et al. Guide of attributes of the nurse's political competence: a methodological study. Rev Bras Enferm [Internet]. 2017;70(3):526-34.

DOI: http://dx.doi.org/10.1590/0034-7167-2016-0483

Submission: 09-29-2016 Approval: 12-04-2016

\section{ABSTRACT}

Objective: To build and validate a guide of attributes of the nurse's political competence. Method: Methodological research. This study comprised the construction of the instrument through literature review; experts validation of pre-established attributes for composing the guide; and clinical validation in the nurses work environment/reality. The data collection took place in the months from August to October 2014, and the analysis was based on the content analysis of Bardin and use of Epi info 3.5. All ethical precepts have been complied with. Results: From 29 attributes found in the literature, 25 have been validated by experts. Clinical/practical validation involved the participation of 43 nurses, who observed that the attributes are not articulated with the professional practices developed by them. Conclusion: The attributes of the nurse's political competence were identified with support of literature. It is concluded that the professionals still have limited and fragmented perception of political competence, expressing difficulty/limitation.

Descriptors: Nursing; Politics; Professional Competence; Professional Practice; Methodological Research in Nursing.

\section{RESUMO}

Objetivo: Construir e validar um guia de atributos da competência política do enfermeiro. Método: Pesquisa metodológica. O estudo compreendeu a construção do instrumento por meio de revisão da literatura; validação, por especialistas, dos atributos preestabelecidos para composição do guia; e validação clínica no ambiente/realidade de trabalho dos enfermeiros. A coleta dos dados ocorreu nos meses de agosto a outubro de 2014, e a análise baseou-se na análise de conteúdo de Bardin e utilização do Epi info 3.5. Foram respeitados todos os preceitos éticos. Resultados: Dos 29 atributos encontrados na literatura, 25 foram validados pelos especialistas. A validação clínica/prática envolveu a participação de 43 enfermeiros, os quais observaram que os atributos não apresentam articulação com as práticas profissionais por eles desenvolvidas. Conclusão: Identificados os atributos da competência política do enfermeiro com apoio da literatura. Conclui-se que os profissionais ainda possuem percepção limitada e fragmentada da competência política, manifestando dificuldade/limitação.

Descritores: Enfermagem; Política; Competência Profissional; Prática Profissional; Pesquisa Metodológica em Enfermagem.

\section{RESUMEN}

Objetivo: Construir y validar una guía de atribuciones de la competencia política del enfermero. Método: Investigación metodológica. El estudio comprendió la construcción del instrumento mediante revisión de la literatura; validación por expertos 
de las atribuciones preestablecidas para composición de la guía; y validación clínica en el ámbito/realidad de trabajo del enfermero. Datos recolectados de agosto a octubre de 2014, analizados según análisis de contenido de Bardin y utilización de Epi info 3.5. Fueron respetados todos los preceptos éticos. Resultados: Fueron encontrados 29 atribuciones en la literatura, 25 fueron validados por los expertos. La validación clínica/práctica involucró la participación de 43 enfermeros, los cuales observaron que las atribuciones no mostraran articulación con las prácticas profesionales por ellos desarrolladas. Conclusión: Identificadas las atribuciones de la competencia política del enfermero, con respaldo en la literatura. Se concluye en que los profesionales tienen aún percepción limitada y fragmentaria de la competencia política, manifestando dificultad/limitación.

Descriptores: Enfermería; Política; Competencia Profesional; Práctica Profesional; Investigación Metodológica en Enfermería.

CORRESPONDING AUTHOR Wesley Soares de Melo E-mail: wesley_161@hotmail.com

\section{INTRODUCTION}

The performance of the nurse as a sociopolitical being implies the ability to articulate different knowledge and attributions, which contributes to the strengthening of the profession and of the class itself. Political action is, therefore, in the capacity of judgment that responds to the needs of the social scenario, representing value perspective, performance and professional placement. It is necessary to build instruments and studies that raise awareness among nurses to the importance of acquisition of political empowerment, since they are social actors who promote improvements in health, in the different contexts in which they act. For that, they need to develop intellectual ability to work in health, act inter-professionally, exert power and critical capacity for interventions in the social environment and workspaces through the triad "abilities, attitude and knowledge".

From this perspective, we commonly observe nurses politically unprepared that, in conflict situations, opt for the easier alternative, approaching or condoning those who hold power. This way, their political ability is annulled and they compose a cluster of divided professionals and subordinates ${ }^{(1)}$.

According to this, nursing has been recognized as a mere bystander to social and political transformations, as it often assumes an uncritical and neutral posture, however ideologically scientific. This makes nursing limited and restricted on the face of exposed situations, and not rare a follower of the biomedical model. In this context, the question emerges: Does this fact result in reduced professional autonomy, political poverty, limitation of the worldview or emphasis of nursing practice in technical procedures unrelated to the social context? Nursing, while social practice, requires the placement of nurses as political agents, which goes beyond technique, provided with a questioning character, a concrete reality apprehension and understanding of their own transforming power in society, capable of issuing judgment and responding to many needs of individuals.

In the scope of Brazilian nursing, the bridges to the past are present and heavily built, to the point that it is not possible to transpose them with punctual actions and of low social impact and without political organization. As they cannot see the other side, with a horizon of libertarian possibilities to the profession, many nurses insist on reproducing the old failed structure of the biomedical model under which they underlie their existence. Thus, without adequate political articulation, our voice is not heard. The inaction raises the belief that little can change and if there is no voice, who will hear us? $?^{(1)}$.
Development of ethical-political competences is a challenge for the training of nurses. When featuring in the construction of integrality of healthcare - recommended as one of the guiding principles of the Unified Health System (SUS) - it becomes imperative that nurses appropriate knowledge, abilities and attitudes, transporting them to the delivery of a competent practice, so that they are, in fact, able to act with a sense of social responsibility and commitment to citizenship, as promoters of integral health ${ }^{(2)}$.

It is important to discuss the ethical and political dimension of the professional competence and propose its development in nursing training to break a vicious circle of justifications for the absence of critical and reflective posture of professionals ${ }^{(3)}$. Development of a broader view on the role of the nurse is also necessary, given the complexity of this training process. In this sense, it is worth questioning: Is there, among such professionals, the real understanding of this political dimension? Are people trained for this? If so, when should this training start? To be ethically competent means dealing with the ethical demand in a critical, reflective and resolutive manner ${ }^{(4)}$. In the face of these problems, which attributes described in the literature meet the political competences of the nurse? What do expert nurses think about the attributes of political competences of the nurse found in literature? Is there awareness and mastery of these essential attributes (found in literature) to consolidate a political character from these professionals working in health units?

As nurses are important figures in the social space, holders of a general profile, participants of the organization, execution and monitoring of the work process, who possess a broad vision about health issues and also occupy strategic spaces, it is necessary to explore and learn about key aspects of their political performance, as well as attributes aggregated to their competence.

On the above, this study is intended to contribute and add efforts to the visibility of nursing in the scope of knowledge and confrontation of abilities and attitudes regarding the political competences of the nurse. To this end, it aims at constructing of a guide of attributes of the nurse's political competence, prepared with the support of literature, as well as checking its content validity among nurses-judges and clinical validity among nurses working in the hinterland of Ceará.

\section{METHOD}

\section{Ethical aspects}

Participants were clarified about the purpose of the survey and invited to participate by signing the Informed Consent 
Form, in accordance with recommendations of Resolution No. 466/12 of the National Health Council (CNS). The study was approved by the Research Ethics Committee (COMEPE).

\section{Type of study}

This is a methodological research, which involves investigation of methods of obtaining and organizing data and conducting rigorous research. Methodological studies deal with development, validation and evaluation of research tools and methods. The growing demands for solid and reliable assessment of results, rigorous testing of interventions and sophisticated procedures for obtaining data have led to an increased interest in methodological research among nurse researchers ${ }^{(5)}$.

\section{Study scenario}

The scenario were mid-sized hospitals and Basic Healthcare Units in the urban area, in the municipalities of Banabuiú, Pedra Branca, Quixadá and Quixeramobim, located in central hinterland of the state of Ceará-Brazil.

\section{Data source}

Population was formed by all nurses working in different sectors (assistance, management and/or education) of health services linked to the mentioned municipalities, selected through some inclusion criteria: a) degree in nursing concluded; b) nurses working in the central hinterland of Ceará, with some kind of employment relationship in these municipalities. The following exclusion criteria were adopted: nurses on health/maternity leave. Sampling technique was decided for convenience, delimited by time period, established by application of inclusion and exclusion criteria.

\section{Data collection and organization}

Data collection took place from August to October 2014, by applying the guide of attributes among nurses. To legitimize the instrument previously prepared, they assessed/responded the instrument containing the items - participants profile, professional characterization, understanding and practice of political competence among nurses, development of such political competence, applicability of attributes on daily life experiences and existence of difficulty/limitations upon the use of these attributes in the experiences of everyday life/reality of work. Then, data were organized in the form of tables, graphics and categorization of the nurses' speeches. To ensure the confidentiality and anonymity of participants, these were identified with the letter " $\mathrm{E}$ " followed by a number (E1 to E43).

\section{Study Steps}

\section{First step of the study}

The instrument was built with support of literature, through the search for publications in the databases Lilacs, SciELO and Medline using the key words: professional competence, policy and nursing, which were crossed with each other. In this step, the following inclusion criteria were established: the publications should answer the guiding questions of the study: a) Is there, among the nurses, a real understanding of this political dimension? b) Are nurses prepared to understand this political dimension? c) If so, when should this preparation start? d) Which attributes described in the literature meet the political competences of the nurse? The publications should be included in the period from 2001 to 2013. For complementation, search of attributes in the literature also used bibliographical references cited in selected publications and contact was made with some researchers who suggested readings with potential to respond to the theme.

Later, a critical reading was conducted to evaluate the consistency of argumentation and trustworthiness of the proposed texts, punctuating the sentences that mentioned properties and characteristics relevant to the character of the nurse's political competence, which allowed the identification of attributes. Also by means of this general exploration of texts, such sentences were organized, converging to final obtainment of the nurse's political competence attributes in the form of simple and objective words. Finally, the attributes were listed and analyzed regarding the bibliographic and semantic basis, in order to make them more trustworthy, obtaining the guide of the nurse's political competence attributes as a final product. It is important to highlight that attribute is defined as the set of knowledge, abilities and attitudes that guide teaching and learning(6). In this perspective, as well as the sum of relevant data on this question and contextual characteristics (background, consequences, socio-cultural and temporal variations), that is, substitute terms related to relevant data concerning the concept application ${ }^{(7)}$.

Following, the classification of attributes was conducted according to the Delors pillars ${ }^{(8)}$, as these constitute a formation based on competence, to better understand which aspects should be present in the performance of the nurse's work, especially the political competence.

The classification of attributes and the decision-making process about to which pillar they belonged occurred through conceptualization of the four pillars and their relationship with the attributes identified. Pillar "Learning to Know": It relates to the act of understanding, discovering, building and rebuilding the knowledge so that it is not ephemeral, remains over time and values the curiosity, autonomy and permanent awareness; Pillar "Learning to $B \mathrm{e}^{\prime \prime}$ : It regards the people's ability of developing themselves as autonomous and critical persons, having their own judgments. Personality and ability, for the individual to grow and develop; Pillar "Learning to Do": It concerns the acquisition of not only a professional technical qualification, but also having potentiality and competences that enable the professional to face many adverse situations. Interacting with the environment developing practices and qualitative knowledge; Pillar "Learning to Live Together": Ability to participate and contribute with others in the development of all human activities. Building collectively. The knowledge in the health field is multiprofessional and transdisciplinary ${ }^{(8)}$.

Finally, the guide (instrument) was obtained, containing questions about the understanding of political competence, how it is shown in the professional practice among nurses, where it was developed and issues related to the aforementioned pillars with their listed attributes. With this process, we sought to assess the degree of applicability of attributes on the experiences of daily life and the existence of difficulty/limitation upon the use of these attributes. 


\section{Second step of the study}

It is characterized by the guide content validity build by nurses-judges. These nurses, named as judges, were selected according to the following criteria: nurses; doctors in nursing; Faculty of public universities in the country; with extensive experience in the themes "nursing care" and "education", health policies, technologies in health care and nursing, nursing and education consulting.

At this point, three nurses assessed the instrument under aspects of appearance, clarity and content. It should be noted that this analytical and thorough assessment generates the production of knowledge, and this analysis conveys meaning to the contents on display ${ }^{(9)}$.

\section{Third step of the study}

It is characterized by checking the clinical validity of the instrument (guide) in the environment/reality of the nurse's work. This step is defined by a descriptive exploratory field research, whose main objective was to contribute to the understanding of the problem-situation faced by researchers. It consists on exploration and searches based on the problem or the situation to obtain the information ${ }^{(10)}$. Therefore, this is a step in which ideas and adjustments are sought to deeply study the theme $\mathrm{e}^{(11)}$.

\section{Data analysis}

The data were analyzed through Bardin's analysis ${ }^{(12)}$ and by the Epi info 3.5 for calculation of absolute and relative frequencies and measures of central tendency (mean, median and mode).

\section{RESULTS}

The instrument built with support of the literature in the first step was submitted to the scrutiny of nurses for content validation, who gave their opinions about appearance, clarity and content. Attributes found were listed according to the four Pillars of Delors ${ }^{(8)}$ : Learning to Know (Self-knowledge; Knowledge; Scientific qualification.); Learning to Be (Autonomy; Creativity; Criticality; Dynamism; Emancipation; Empowerment; Strength; Leadership; Power; Proactivity; Representativeness; Resilience; Vision); Learning to Do (Coordination; Entrepreneurship; Innovation; Personal Marketing; Negotiation; Mobilization; Politicality of care; Resolvability; Decision-making.); Learning to Live Together (Otherness; Interaction; Interpersonal relationships; Teamwork). In this sense, the nurses-judges suggested modifications, such as the withdrawal of some attributes (resolvability and politicality of care from the pillar Learning to Do; vision and emancipation from the pillar Learning to Be) for not considering them to be pertinent to the nurse's political competence or for believing they were related to other pillars.

Subsequently, the enhanced instrument was applied among the 43 nurses who participated in this study in their respective working places, generating data about professional characterization, place of work and attributes of the political competence, which will be described hereinafter.

Most of the nurses were female $(83.7 \%)$, aged between 23 and 50 , average age of 32 years old (6.57 years). In relation to training, the maximum number was 21 years, the minimum 1 year, and average of 6.52 years (4.84 years). Regarding title, there was a greater number of experts $(76.7 \%)$, but no participant had the Phd academic title. Concerning health care level, most of participants played roles in primary health care $(44.2 \%)$, some acted in the secondary (34.9\%) and tertiary sector $(2.3 \%)$ and others in the secondary and tertiary sectors $(2.3 \%)$, respectively. Regarding the process of the nurse's work, $69.8 \%$ worked with nursing care.

Evaluations carried out by nurses about clinical practice are described. They evaluated the guide of attributes in relation to the following aspects: applicability of attributes of political competence in everyday experiences; difficulties and/or limitations (policies) in the training and execution of the work; and location of the training start and development of political character. The findings organized into the four pillars of Delors and their respective attributes are presented in Table 1 . In Table 2, the results concerning the development of political character are shown.

Table 1 - Evaluation of attributes by Pillar of political competence of the nurse, Quixadá, Ceará, Brazil, 2014

\begin{tabular}{|c|c|c|}
\hline Attributes listed by pillars & $\begin{array}{c}\text { Applicability } \\
\text { in everyday } \\
\text { experiences }(\%)\end{array}$ & $\begin{array}{l}\text { Difficulty/ } \\
\text { Limitation } \\
\quad(\%)\end{array}$ \\
\hline \multicolumn{3}{|l|}{ Pillar "Learning to Know" } \\
\hline Knowledge & 90.7 & 60.5 \\
\hline Scientific qualification & 72.1 & 74.4 \\
\hline Self-knowledge & 55.8 & 62.8 \\
\hline \multicolumn{3}{|l|}{ Pillar "Learning to $\mathrm{Be}^{\prime}$} \\
\hline Autonomy & 60.5 & 72.1 \\
\hline Dynamism & 58.1 & 72.1 \\
\hline Creativity & 53.5 & 72.1 \\
\hline Leadership & 53.5 & 69.8 \\
\hline Empowerment & 51.2 & 72.1 \\
\hline Representativeness: & 51.2 & 65.1 \\
\hline Proactivity & 48.8 & 67.4 \\
\hline Strength & 46.5 & 67.4 \\
\hline Criticality & 41.9 & 72.1 \\
\hline Resilience & 34.9 & 74.4 \\
\hline Power & 32.6 & 76.7 \\
\hline \multicolumn{3}{|l|}{ Pillar "Learning to Do a" } \\
\hline Coordination & 74.4 & 67.4 \\
\hline Decision-making & 62.8 & 72.1 \\
\hline Mobilization & 60.5 & 72.1 \\
\hline Negotiation & 60.5 & 72.1 \\
\hline Innovation & 44.2 & 69.8 \\
\hline Personal marketing & 39.5 & 69.8 \\
\hline Entrepreneurship & 34.9 & 69.8 \\
\hline \multicolumn{3}{|l|}{ Pillar "Learning to Live" Together } \\
\hline Teamwork & 93 & 44.2 \\
\hline Interpersonal relationship & 90.7 & 41.9 \\
\hline Interaction & 76.7 & 44.2 \\
\hline Otherness & 23.3 & 81.4 \\
\hline
\end{tabular}




\section{Political character development}

With regard to the development of the political character of nurses, $48.3 \%$ of respondents answered that this began in the daily work, according to table 2 .

Table 2 - Formation and development of the political character, Quixadá, Ceará, Brazil, 2014

\begin{tabular}{lc} 
Training environment and political character development & $\%$ \\
\hline Everyday work & 48.3 \\
Academic & 23.3 \\
Conferences and associations & 23.3 \\
No answer & 4.6 \\
\hline
\end{tabular}

\section{DISCUSSION}

Predominance of women refers to socio-historical aspects of the profession. Although in recent years the percentage of male nurses has increased, the attraction of university education has not been enough appeal for them to consider nursing as a professional option ${ }^{(13)}$.

In a study, significant portion of nurses (73.4\%) reported having a lato sensu postgraduate course. However, no professional declared stricto sensu postgraduate studies (master's and/or doctor's degree) ${ }^{(14)}$.

It is also possible to infer that as the majority of the public develops activities within the framework of assistance, they seek only specialization courses. Since master's and doctor's degrees are more associated with projects of construction of a teaching career, even though these degrees also enable conditions for a better assistance and remuneration in the act of caring, are more associated to projects of construction of a teaching career.

Particularly in this study, one can see the prevalence of nurses acting in the primary health care $(\mathrm{PHC})$, due to have been held in municipalities in the interior of the state of Ceará, in the central hinterland. There is also the new health care paradigm defined by the Unified Health System policies, which values the importance of Basic Healthcare $(\mathrm{BH})$ and institutionalizes changes in the assistance model aiming at reorganization of health services in order to better respond to the health needs of the population, which involve changes in the training of professionals.

In this sense, there is evidence that at the $\mathrm{BH}$ level, the nurse must take on the role of central protagonist in this working process, being able to set directions determined by technical, ethical and political spheres ${ }^{(14)}$.

Following, the pillars that subsidized the construction of the guide of attributes of the nurse's political competence will be discussed.

\section{Pillar "Learning to Know":}

The majority of respondents referred being able to apply these attributes in everyday experiences, while many revealed difficulties or limitations for that. It is worth highlighting that the knowledge is inherent to the nurse's work and it is not possible to perform the assistance, education, management and research without it ${ }^{(15)}$.

... I must qualify not only technically, I should be ready to receive criticism and also be open to drink from other types of knowledge... (E42)

The nurse continually enhances knowledge, which should be mediated among the technical, political and ethical aspects... (E14)

Reports of participants also allow to infer that knowledge must be combined with the scientific qualification, in order to promote the acquisition of certain power and ability to intervene in the social environment.

It contributes so that every day I find more and more the improvement of my practice, researching, producing, experiencing. (E23)

... ability to intervene on social reality. (E34)

... reconcile the caring and nursing processes with the social causes. (E35)

It becomes imperative that nursing, as a profession, develops a relevant body of knowledge and abilities to consolidate its position as science and meet the changes necessary to social plan, no longer under a fragmented vision to address complex problems. It is necessary to work on fruitful understanding of the social commitment of profession with quality of life and health of people, articulating research and extension in the training of nurses, as to provide greater credibility to this profession. Diffusion of knowledge expands discussions and reflections which, in their turn, provide feedback to production ${ }^{(16)}$. However, despite the advances made possible by the scientific production, there is still a challenge to transfer knowledge to the nursing and health practice ${ }^{(17)}$.

As a science, Nursing has a body of values, knowledge and theories, which are applied and incremented during the training of nurses and enhanced through research. However, there is a redundancy situation, because these values and knowledge, backed up by the scientific character, fall apart in practice, thus becoming an ephemeral and abstract knowledge, a qualification restricted to the "paper," of only theoretical consummation. For this professional class to increasingly advance, it is necessary to apply in practice the knowledge acquired through scientific qualification and production, in order to achieve the greatest impact in the advancement of knowledge and clarify its relevance to society.

\section{Pillar "Learning to Be"}

The little applicability of attributes is observed in this pillar. It also concentrates the greatest degree of difficulty/limitations.

The study pointed out some obstacles to political empowerment of nurses in practice, including workplace permeated by dissatisfaction, frustration, absenteeism, accommodation, conformism, demotivation, lack of social commitment, 
commitment, interest and responsibility of nurses, as well as reduced autonomy due to reproduction of the biomedical model and subordination, submission and dependence on the medical professional. It also identified the performance of this professional still very restricted to medical prescription, which affects problem-solving by the nurse, and difficulties related to the fact that the institution centers health production in the medical professional class. The performance of the nurse was compared to a freelancer's, i.e., still very mechanistic and technical, with discontinuity and fragmentation of care and a work environment permeated by conflicting relations among other professionals, which makes the proposal of emancipatory practice difficult for this professional ${ }^{(18)}$.

Given this, the political ability of the nurse emerges as a way to deal with obstacles of the professional practice.

It is the ability of dealing with difficulties of everyday life [...] on how we can turn those odds in our favor. (E35)

It is the ability to act on the basis of a critical reflection coupled with commitment to the human being, society and profession. (E34)

The knowledge and the search for professional autonomy articulate with the need for political activity to enhance credibility of the profession ${ }^{(19)}$, whose contents need to be known to facilitate the exercise of autonomy, because the role of the nurse is supported by scientific knowledge rather than by medical prescription. Possession of knowledge implies autonomy of action, since it allows respectability and reliability amongst professionals, in addition to confer visibility and add valuable aspects to the job.

In the reports of nurses it is noted that criticality must be allied in the whole nursing praxis as an attribute of strengthening. For this professional category it reinforces the production of their own values and principles, in favor of greater autonomy and prestige.

... critical and reflective view, as well as their technical/scientific/practical knowledge. (E20)

Assistance based on critical performance, [...] and starts to act autonomously. (E21)

... be critical and an opinion maker to perform health activities of this class. (E42)

Nurses recognize the need of the ability to think, of the development of critical thinking of the profession, of a performance based on the cultural approach and the appropriation of the complex dimension of health training ${ }^{(2)}$.

Study conducted with nurses showed, through reports of the participants, that to develop leadership it takes agility, criticality, creativity, otherness, power of organization, communication and negotiation ability, as well as keeping up with the dynamism of health processes ${ }^{(20)}$.

In addition, it is necessary that nurses develop and make their acting power and influence visible in the social and health scenario, so that others recognize the importance of their work. This posture encourages the achievement of their due credibility and accreditation.

Power of transformation not only within the team. (E25)

In the creation of professional autonomy and empowerment of the people around us. (E28)

Social interaction establishing trust and a better personal interaction. (E4)

... to exercise personal and social relations conquering space for their actions. (E9)

It is noted in the reports that such attributes permeate the abilities, attitudes, knowledge and have full relationship between themselves, establishing a cyclical, interdependent and continuous process for the development of this professional, thus it is not relevant to fragment them.

\section{Pillar "Learning to Do"}

There is a marked difficulty/limitation in applying the attributes of this pillar, except coordination, which highlights certain unpreparedness in the professional class.

It is known that the autonomy emerges as an indispensable condition to express innovation and creativity in the execution of health actions. Experiencing innovation, creativity and decision-making informed by better evidence is possible and necessary for better results in health ${ }^{(21)}$.

This is a context that emphasizes the role of research and scientific knowledge as strategies to promote and evidence these attributes, and their subsequent application for the confrontation of health problems. As mentioned, the unpreparedness, expressed in the form of difficulty and limitation on scientific qualification, and impotence in autonomy reflect a category with low potential for innovation, creativity and resolution power.

Therefore, the nurse's political competence is understood as:

Actions and knowledge that support nurses in their practice and facilitate decision-making. (E1)

...all nursing decisions are taken based on scientific evidence. (E7)

Questioning the ways of acting and thinking. (E9)

In face of the conflicts, nursing still acts with restriction in the collective spaces and in the class itself; it has a complicated and uncertain relationship in the interaction with the whole, being invisible, so that the negotiation is essential in the political sphere, because:

It is the one that governs relations, manages the conflicts. (E8)

This is the power of resolution ... (E10)

Negotiation, in turn, requires leadership abilities. Nurses need to promote personal marketing to internal and external clients, thus evidencing their potential and increasing their visibility to 
gain prestige. Dynamism and entrepreneurship are also needed as attributes to obtain autonomy in the work process ${ }^{(22)}$.

The attribute of mobilization, along with personal marketing, is valuable in the political dimension and, therefore, nurses must widely develop and apply it, because they are directly involved in all health actions and work in teams which often have a good reliability degree. They are still considered key agents of health policies and committed to health care in the most diverse levels.

...our work should cause a transformative and mobilizing action to customers cared by us. (E22)

Political competence contributes in the everyday life through attitudes we take in social context, inside and outside the institution. (E33)

\section{Pillar "Learning to Live Together"}

Based on the reports, it is verified that nurses achieve a great applicability of these attributes in everyday life.

The study pointed out that the principle of otherness guides attitudes of nursing professionals; attitudes that do not observe this principle may open spaces for the emergence of feelings of powerlessness and limitation. When the principle of otherness is considered, the nursing actions begin to meet the demands, and there is also professional satisfaction in the work process ${ }^{(23)}$.

Interaction and relationships that assume otherness and resilience are fundamental, essential virtues for teamwork ${ }^{(24)}$.

$$
\begin{aligned}
& \text {... the policy assists us in the teamwork. (E8) } \\
& \text {... union of professionals of the class. (E41) }
\end{aligned}
$$

Nurses, in the condition of professionals who experience multiple relationships in the context of their work, should abstain from monological interactions, which bring no benefit. They should really know to work as a team and recognize the ability and quality of the other, because dealing with differences and adversities is critical for their growth. Learning with the opinion and attitudes of others allows to extend knowledge and reflective capacity. The space of politics tend to lose their concreteness on modern experience of human living.

\section{Political "Character development"}

It is known that it is in the practical experience that abilities, attitudes and knowledge acquired during the training are demonstrated, which strengthen over time and thus enhance the professional capacity and experience. This process becomes more difficult, however not rare, when the professional is exposed to everyday work without knowledge or prior training.

In this sense, it is argued that the time of graduation is appropriate and fruitful to work and develop such competence in the pupil, as it is during training that the figure of the future professional is built and shaped, aggregating values and different types of knowledge. Even though the technical dimension composes a good part of the curricular matrix of Nursing courses, the health system needs and demands political and ethical competences that promote the recognition of nurses as full and competent professionals.
Therefore, for their development, it is essential the implementation of a teaching program inserted in the current context of health and that also includes training based on political dimension. It is considered that the process of vocational training should provide students with experiences of reality that instigate them to reflect and act on the ethical-political context of health care where the conscious performance of the professional nurse is inserted ${ }^{(2)}$.

In addition to graduation, it is crucial that the nurses are updated on their training and seek trainings in conferences. They must also be active in the bodies and associations of their competence, promoting their qualification. It is necessary to fight: appreciation of the technical dimension, limiting it to the one encoded of the profession and with little reference to the political dimension; The teaching model in which these teachers were formed (traditional and technical); The absence of political participation of the majority of teachers nurses; The overspecialization in perspective of the labor market, leading to the fragmentation of care which, most of the times, collides with the purposes currently recommended by the Brazilian health system.

\section{Study limitations}

During this study, some limitations were found, including availability and difficulty of nurses to answer the questionnaire on this issue.

\section{Contributions to the Nursing field}

To minimize this situation of limited or absent critical and reflective posture, nurses must experience the attributes of political competence while they're still in the process of professional training in undergraduate courses in nursing, through vocational guidance, participation of student movements, courses or events and disciplines aiming at constant improvement, consolidation of knowledge and enhancement of their politicality. Thus, it is necessary that this competence is addressed and worked intensively as to transform the trajectory of nursing. For this, it is imperative to reiterate that nurses are active and decisive figures in health spaces, have their own autonomy, are opinion makers, as well as representative in the middle of those that make up the health system and civil society.

\section{CONCLUSION}

In this study, the attributes of political competence of nurses were identified with support of literature, validated with nurses-judges, thus obtaining the guide of attributes of their political competence; later, this instrument was also validated/ applied clinically with the professionals of assistance, management and teaching areas, and in different levels of health care (primary, secondary, tertiary).

It can be observed that nurses still have a limited and fragmented perception about what is political competence. Conceptions and pragmatisms deriving from it are considered partial and limited, often restricting to just a few of the various attributes and concepts that permeate this dimension of professional activity. A need in relation to the knowledge of 
the attributes of political competence by nurses can also be observed, as there is no articulation of these with the practice, featuring a relatively unprepared professional class, with vocation directed to the technical know-how.

It was also verified that nurses, even achieving the applicability of attributes on the everyday life experiences, always demonstrated some difficulty or limitation. The pillars "Learning to $\mathrm{Be}^{\prime \prime}$ and "Learning to Do" presented higher index of difficulty compared to others, which is justified by the fact that the attributes of these pillars demand from professionals the ability of connecting types of knowledge, making good use of professional posture, as well as having their values added throughout their practical performance. Based on this, it is necessary to emphasize that the success comes from a joint application of all attributes, establishing an integration, according to a cyclical and codependent process.

\section{REFERENCES}

1. Lessa ABSL, Araújo CNV. A enfermagem brasileira: reflexão sobre sua atuação política. REME Rev Min Enferm [Internet]. 2013 [cited 2014 Feb 05];17(2):474-80. Available from: http://www.reme.org.br/artigo/detalhes/664

2. Meira MDD, Kurcgant P. O desenvolvimento de competências ético-políticas segundo egressos de um Curso de Graduação em Enfermagem. Rev Esc Enferm USP [Internet]. 2013 [cited 2014 Aug 19];47(5):1211-8. Available from: http://www.scielo.br/pdf/ reeusp/v47n5/pt_0080-6234-reeusp-47-05-1203.pdf

3. Burgatti JC, Leonello VM, Bracialli LAD, Oliveira MAC. Estratégias pedagógicas para o desenvolvimento da competência éticopolítica na formação inicial em Enfermagem. Rev Bras Enferm [Internet]. 2013 [cited 2014 Aug 19];66(2):282-6. Available from: http://www.scielo.br/pdf/reben/v66n2/20.pdf

4. Paganini MC, Egry EY. The ethical component of professional competence in nursing: an analysis. Nurs Ethics [Internet]. 2011 [cited 2014 Aug 20];18(4):571-82. Available from: http://nej.sagepub.com/content/18/4/571.abstract

5. Polit DF, Beck CT. Fundamentos de pesquisa em enfermagem: avaliação de evidências para a prática da enfermagem. 7a ed. Porto Alegre: Artmed; 2011.

6. Paranhos VD, Mendes MMR. Competency-Based Curriculum and Active Methodology: Perceptions of Nursing students. Rev Latino-Am Enfermagem [Internet]. 2010 [cited 2014 Aug 20];18(1):109-15. Available from: http://www.scielo.br/pdf/rlae/ v18n1/17.pdf

7. Rodgers BL. Concept analysis: an evolutionary view. In: Rodgers BL, Knafl KA. Concept development in nursing: foundations, techniques and applications. 2a ed. Philadelphia: W.B Saunders; 2000.

8. Delors J. Educação: um tesouro a descobrir. Relatório para a UNESCO da Comissão Internacional sobre Educação para o Século XXI. 8a ed. São Paulo: Cortez; 2003.

9. Tognoli D. Interpretação e Análise: Pesquisa qualitativa. In: Perdigão DM, Herlinger M, White OM, Franceschini A, Gropp BMC, Moreira BD, et al. Teoria e prática da pesquisa aplicada. Rio de Janeiro: Elsevier; 2012. p. 161-167

10. Malhotra NK. Pesquisa de Marketing: Uma orientação aplicada. 6a ed. Porto Alegre: Bookman; 2012.

11. Veloso WP. Metodologia do trabalho científico: normas técnicas para redação de trabalho científico. 2a ed. Curitiba: Juruá; 2011.

12. Bardin L. Análise do Conteúdo. 1a ed. São Paulo: Edições 70; 2011.

13. Furukawa PO, Cunha ICKO. Perfil e competências de gerentes de enfermagem de hospitais acreditados. Rev Latino-Am Enfermagem [Internet]. 2011 [cited 2014 Apr 20];19(1):106-14. Available from: http://www.scielo.br/pdf/rlae/v19n1/pt_15.pdf

14. Correa ACP, Araújo EF, Ribeiro AC, Pedrosa ICF. Perfil sociodemográfico e profissional dos enfermeiros da atenção básica à saúde de Cuiabá - Mato Grosso. Rev Eletr Enf [Internet]. 2012 [cited 2014 Nov 08];14(1):171-80. Available from: http://www.fen.ufg.br/ revista/v14/n1/pdf/v14n1a20.pdf

15. Fentanes LRC, Hermann AP, Chamma RC, Lacerda MR. Autonomia profissional do enfermeiro: revisão integrativa. Cogitare Enferm [Internet]. 2011 [cited 2014 Nov 08];16(3):530-5. Available from: https://www.fen.ufg.br/fen_revista/v14/n1/pdf/v14n1a20.pdf

16. Alvim NAT. Production and dissemination of nursing scientific knowledge today: challenges and implications for education and qualification of nurses. Esc Anna Nery Rev Enferm [Internet]. 2010 [cited 2014 Nov 10];14(1):07-09. Available from: http://www. scielo.br/pdf/ean/v14n1/en_v14n1a01.pdf

17. Scochi CGS, Munari DB, Gelbcke FL, Erdmann AL, Gutiérrez MGR, Rodrigues RAP. Pós-graduação Stricto Sensu em Enfermagem no Brasil: avanços e perspectivas. Rev Bras Enferm [Internet]. 2013 [cited 2014 Nov 10];66(spe):80-9. Available from: http://www. scielo.br/pdf/reben/v66nspe/v66nspea11.pdf

18. Porto AR. O empoderamento político dos enfermeiros na prática hospitalar [dissertação]. Universidade Federal de Pelotas; Pelotas. 2011.

19. Bellaguarda MLR, Padilha MI, Pereira NAF, Pires D, Peres MAA. Reflexão sobre a legitimidade da autonomia da enfermagem no campo das profissões de saúde à luz das ideias de Eliot Freidson. Esc Anna Nery Rev Enferm [Internet]. 2013 [cited 2014 Nov 12];17(2):369-74. Available from: http://dx.doi.org/10.1590/S1414-81452013000200023 
20. Araszewski D, Bolzan MB, Montezeli JH, Peres AM. The exercising of leadership in the view of Emergency room nurses. Cogitare Enferm [Internet]. 2014 [cited 2014 Nov 12];19(1):41-7. Available from: http://revistas.ufpr.br/cogitare/article/view/35933/22410

21. Silva SF, Souza NM, Barreto JOM. Fronteiras da autonomia da gestão local de saúde: inovação, criatividade e tomada de decisão informada por evidências. Ciênc Saúde Colet [Internet]. 2014 [cited 2014 Nov 27];19(11):4427-38. Available from: http://www. scielo.br/pdf/csc/v19n11/1413-8123-csc-19-11-4427.pdf

22. Manenti SA, Ciampone MHT, Mira VL, Minami LF, Soares JMS. The construction process of managerial profile competencies for nurse coordinators in the hospital field. Rev Esc Enferm USP [Internet]. 2012 [cited 2014 Apr 20];46(3):727-33. Available from: http://www.scielo.br/pdf/reeusp/v46n3/en_27.pdf

23. Tome LY, Popim RC, Dell'Acqua MCQ. Enfermagem cuidando de paciente adulto e família no processo de morte em sala de emergência. Cienc Cuid Saude [Internet]. 2011 [cited 2014 Nov 20];10(4):650-7. Available from: http://dx.doi.org/10.4025/ cienccuidsaude.v10i4.18307

24. Cotta RMM, Costa GD, Mendonça ET. Portfólio reflexivo: uma proposta de ensino e aprendizagem orientada por competências. Ciênc Saúde Colet [Internet]. 2013 [cited 2014 Nov 25];18(6):1847-56. Available from: http://dx.doi.org/10.1590/S1413-81232013000600035 